„Przekłady Literatur Słowiańskich”. T. 10, cz. 2

ISSN 2353-9763 (wersja elektroniczna)

DOI https://doi.org/10.31261/PLS.2020.10.02.07

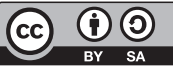

\title{
Предизвиците на преводот на \\ Киберијадата од Станислав Лем
}

\section{The Challenges of Translating The Cyberiad by Stanisław Lem}

\author{
Lidija Tanuševska \\ iD https://orcid.org/0000-0001-5465-960X \\ SS. CYRIL AND METHODIUS UNIVERSITY IN SKOPJE \\ lidkapol@yahoo.com \\ Data zgłoszenia: 7.09.2019 r. | Data akceptacji: 10.02 .2020 r.
}

\begin{abstract}
This article is about the specific language that the translator is faced with translating The Cyberiad by Stanisław Lem and some of the difficulties that are caused by the conception of the whole book. Considering that it is a science-fiction, it is natural that the main problems are neologisms made by Lem, but it appears that it is not the only one. We are trying to make an outline of the whole process of translating The Cyberiad, underlining some of the difficulties that the translator in Macedonian language could have come upon. Analyses contains of problems with word formation, poetic language, phraseology, archaisms and neologisms.
\end{abstract}

KEYWORDS | science-fiction, language, stylization, arhaisms, neologisms 
Фасцинацијата со научната фантастика на Станислав Лем на македонската почва започнува во 1975 г., со првиот превод на македонски на неговото дело „Непобедлив“ („Niezwyczężony“), чиј нов превод излезе кон крајот на 2019 г., потоа, во 1989 г. е преведен „Соларис“, а по долга пауза од речиси дваесет години, излегува вториот превод на „Соларис“ и во 2018 г. „Киберијада“, за првпат на македонски јазик. Се разбира, македонската читателска публика не се ограничува само на македонскиот јазик - во периодот на поранешната Југославија Лем се читал и на српскохрватски, а во поново време, со напреднатата технологија, и на англиски јазик. Она што го прави Лем оригинален и различен од другите автори на овој жанр е неговото прекршување на научно-фантастичната традиција на утопијата преку политичката проблематика, прикажување на алчната власт преку алегорија и сатира, прикажувањето на ирационалниот елемент во самата идеја на владеењето, апологијата на другоста и на отуѓеноста во светот на технократијата и сл. Така и во „Киберијада“ се појавува оригинална компонента на бајковитата научно-фантастична визија на иднината, односно, „покрај политичарот жеден за власт, еден „политичаризумител“... кој сака да создаде општество-механизам кое не само што ќе функционира совршено и на огромно задоволство на граѓаните, туку и ќе биде во состојба самото да се поправа и да ги одржува своите функции без ингеренции од страна на творецот “1.

Се разбира, она што го прави овој автор оригинален е и јазикот, односно стилот на пишување. Во тој поглед, како врвно негово дело се истакнува „Киберијадата“, бидејќи никој дотогаш не успеал на таков начин да ја вкрсти футуристичката фантастика со бајката и филозофскиот кус расказ, никој нема направено таква мешавина од „научно-технички“ материјал со бајковита подлога на претставениот свет. „Лем посегнал по јазичните извори на старополскиот јазик со многу шокантна цел... приказните од идната ера на роботи да ја раскаже со застарен јазик, во барокната проза на благородничката гачка... пародија на филозофски кус расказ во волтеријански стил, пародија на бајка за деца, пишувана во римувана проза, пародија на псевдофилозофски трактат и, на крајот, мајсторска имитација на палимпсест во источњачки стил“2. Имено, предизвици за преведувачот на „Киберијадата“ се зборообразувачките модели кои ѝ даваат сатиричен тон на приказната, поетскиот стил,

1 J. Jarzębski, 1983: Science fiction a polityka. „Pamiętnik Literacki”, R. 74, z. 2, s. 89-90 (заб. сопствен превод од полски на македонски на цитатот).

2 S. Grochowiak, 1965: Jaki śmieszny Lem! „Nurt”. Dostępne w Internecie: https://sola ris.lem.pl/ksiazki/beletrystyka/cyberiada/351-recenzja-cyberiada-jaki-smieszny-lem [dostęp: 7.09.2019] (заб. сопствен превод од полски на македонски на цитатот). 
фразеологизмите својствени за разговорниот јазик, бројните архаизми и, на крајот, се разбира, лемовите неологизми. Овој текст ќе ги опфати токму овие преведувачки проблеми, преку анализа на избрани примери од секој тип во оваа рамковна класификација во преводот на „Киберијадата“ на македонски јазик.

Во стилот на Станислав Лем многу често се среќаваат неологизми кои се изведени од веќе постоечка лексема со невообичаена за неа префиксација или суфиксација или, пак, со образување сложенка со друга лексема, за означување на некој нов збор. Така, на пример, во „Третото патешествие“ се појавува „општата теорија на змејовите или змејологија“, како наука за докажување на веројатноста на постоењето на змејовите, па во врска со тоа, се појавуваат и многу нови зборови изведени од лексемата „змеј“. Во голем дел од овие примери зборообразувачките модели во полскиот и во македонскиот јазик се поклопуваат, иако основната лексема е различна, што се должи на блискоста на словенските јазици. За илустрација ќе послужат следниве примери:

Poligon smokorodny, smokoligon - змејороден полигон или змејолигон (полигон на кој слетуваат змејови); smokon - змејон (единица мерка за змејови); niedosmok - недозмеј (недораснат, мал по раст змеј); smokoliza змејолиза (анализа на змејови); smokotron - змејотрон (генератор на змејови) smokomacierz - змејоматрица (матрица на змејови).

Проблем се појавува во следниов пример, кој бара поголема вештина и креативност на преведувачот, токму поради различната лексема во двата јазика од која се изведени сите останати неологизми:

Prawdopodobnie wyskrobuje „»” z matrycy i wstawia tam „a”. W ten sposób smok pojawia się od razu w szale — smok $\mathrm{z}$ amokiem. ${ }^{3}$

Авторот на македонскиот превод се справил со оваа ситуација на сличен начин како што е наведено во оригиналот, одземајќи ги првите две букви од лексемата и заменувајќи ги со „луд“, при што добил нов неологизам, за разлика од полскиот текст, каде што се работи за лексема која означува „лудило“, но и натаму тоа е во стилот на Лемовото играње со зборообразувачките модели при што е задржано и значењето во оригиналот:

Најверојатно гребе „зм“ од матрицата и на негово место става „луд“. На тој начин змејот веднаш се појавува со лудило - змеј-лудеј. ${ }^{4}$

3 Сите примери во оригинал се од електронското издание: S. Lem, 2012: Cyberiada. Kraków, Cyfrant, s. 67 [e-book].

4 Сите примери на македонски се од изданието: С. Лем, 2018: Киберијада. М. Миркуловска, прев. Скопје, Антолог, s. 99. 
Поилустративна за начинот на создавање неологизми со суфиксација е следнава низа лексеми, во чија основа лежи „машина“:

Jedni byli maszynowcami, inni maszynistami, jeszcze inni maszynalami; a każdy miał własną maszynistkę. ${ }^{5}$

Се работи за роботи кои извршуваат некакви дејности поврзани со машините, па соодветни се и суфиксите за лица кои вршат некоја дејност: -owiec, -ista/-istka, а останува загатка суфиксот -ał. Соодветно и во македонскиот превод се употребени суфиксите кои се употребуваат за истата група лексеми, со тоа што и во македонскиот е употребен суфиксот - $а л$, кој не секогаш означува лице, особено не поврзано со вршење дејност:

Едните биле машиначи, другите машинисти, а уште таму некои други машинали; секој си имал сопствена машинистка. ${ }^{6}$

Значењата на овие лексеми во полскиот оригинал и во македонскиот превод донекаде се поклопуваат: maszynowiec - според суфиксот повеќе би одговарал на машинеи, но преведувачката создала неологизам машинач, што сепак не одбегнува од стилот на Лем, но не го содржи тоа значење; maszynista/мaшuнист и на двата јазика го има истото значење; maszynał/машuнал и на двата јазика наликува на неологизам; а во ваков контекст полската maszynistka има значење на секретарка, односно жена која работи на машина за пишување, што, впрочем, би можело да биде и скриено значење на македонската машинистка, но не е и основното.

Една од одликите на стилот на „Киберијадата“ е поетичниот стил, што во многу делови од текстот се пројавува во максималната интеракција меѓу звукот и значењето, во еуфоничноста на пораката. За преведувачот, тоа е следниот предизвик. Понекогаш директен трансфер на поетичноста на истиот фрагмент се чини невозможен во истата мера, но преведувачот го постигнува ефектот на оригиналот на некое друго место. Како илустрација ќе послужи следниов фрагмент:

A ona już na całe niebo im wlazła i pali, smali, ryczy, syczy, aż im się księżyc skurczył i osmalił z obu rogów, a chociaż popękany, stary, mały, to i takiego żal. Więc już nic nie mówili, tylko wzięli jedno bardzo silne pole, związali mu po supełku w każdym rogu i włączyli kontakty: niechaj za nas mówią fakty. Hukło, trzasło, zajęczało, niebo zaraz pojaśniało, z komety została tylko kupka żużlu i znowu spokój. ${ }^{7}$

5 S. Lem, 2012: Cyberiada..., s. 91.

6 С. Лем, 2018: Киберијада..., s. 135.

7 S. Lem, 2012: Cyberiada..., s. 91. 
А таа веќе по небо сето, им влегла и пали, жари, рика, шишка, што и месецот им се смалил и се саѓосал од двата краја, сепак испукан, стар, мал, навистина да ти е жал. Простум ништо не си рекле, само едно мошне силно поле довлекле, па јазолче му врзале по секое крајче и го вклучиле в штекерче: за нас нека зборат факти. Бувна, тресна, јачна, небо бргу светна, од кометата останало само купче згури - и повторно мир. ${ }^{8}$

Преведувачот внимавал на парономастичноста, постигнувајќи ја со рими и лексеми што слично звучат или имаат исти завршетоци, набројувањата, исто така, придодаваат еуфоничност на текстот, применета е инверзија на одредени именски синтагми, што е типично за поезијата во македонскиот јазик, а семантичноста е нагласена со складноста на синтаксичките конструкции и вметнувањето архаизми со поетскиот израз.

Интересен предизвик за поетски превод поставува и самиот Лем, кога изумителот Трурл ѝ дава задача на машината да состави песна, во која сите зборови треба да бидат на одредена буква, да има рима и најмногу шест стиха, а ќе ја опејува љубовта и изневерата, музиката, црномурестите, повисоките сфери, несреќата, родосквернавењето.

Cyprian cyberotoman, cynik, ceniąc czule

Czarnej córy cesarskiej cud ciemnego ciała,

Ciągle cytrą czarował. Czerwieniała cała,

Cicha, co-dzień czekała, cierpiała, czuwała...

...Cyprian ciotkę całuje, cisnąwszy czarnulę!!"

Македонскиот преведувач излегол на крај со овој предизвик, применувајќи го латинското писмо и играјќи со двознаците, слично како

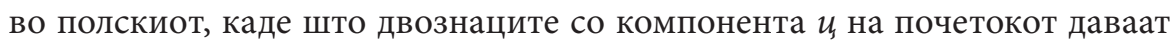
различни звукови вредности:

Ciprijan ciberotoman, cinik, cenejki chujno

Crna cherka carska, chudno crno celo,

citra chesto civkal. Crveneela cela,

celovremeno chekala, chuela, crcorela...

...Ciprijan cecasi celuva, chuknuvajkji Crnkata!! ${ }^{10}$

При тоа, преводот е доста „верен“ на оригиналот - речиси секој збор е доследен еквивалент на оригиналниот. Римата, пак, речиси и ја нема.

8 С. Лем, 2018: Киберијада..., s. 136.

9 S. Lem, 2012: Cyberiada..., s. 45.

10 Ibidem, s. 63. 
Овој стил на запис на македонскиот јазик, со латинско писмо и со двознаци, преведувачката го црпи од актуелното пишување распространето по социјалните мрежи.

Овој фрагмент од „Киберијадата“ е искористен и како инспирација за креативно творење во проектот „Станислав Лем на 100 светски јазици“, кој е еден од неколкуте планирани изданија по повод 100 години од раѓањето на Станислав Лем во 2021 г. Во рамките на овој проект планирано е издавање книга со расказот на Лем во кој е поместен овој фрагмент на полски јазик и фрагментот преведен на околу стотина јазици. Со оглед на тоа дека секој преведувач различно преведува, многу често се случува да има и неколку преводи на истиот јазик, а бидејќи е тешко да не се одговори на овој предизвик и самата направив превод на песната, кој се разликува од оној на официјалниот превод на македонски јазик:

Киберотоманот Кипро, к’не, копнеж имал крепка

по красната ќерка на калешо крале,

која со кемането катаден ја ќарел.

А ќеф да му има крвта негова, каданата кревка,

казнета на карасевда, ѝ клокоти крвта, корне коса...

к'смет имал Кипро, за неа калешвицата ја кошнал.

Се одлучив буквата на која ќе започнуваат зборовите да биде „к“, а не „ц“ - поради насловот на самата книга - Киберијада, додека во полскиот е Cyberiada. Неколку зборови ја содржат и буквата „к“ која, сепак, е само помека варијанта на „к“, а се протнуваат и зборови на други букви, особено предлозите и кратките заменски форми, кои се решив да ги задржам поради желбата да не се нарушува синтаксата на јазикот и поради еуфоничниот ефект. Содржината е прилично различна од оригиналот, личното име е адаптирано на македонската традиција, музичкиот инструмент е сменет со архаичен регионален елемент, кој е сличен на тој во оригиналот, „тетката“ е неодредена личност која е во крвно сродство со главниот јунак, a „Црнката“ е само „калеша“, што не мора да е расна квалификација. Затоа, пак, римата е функционална.

Како што беше напоменато погоре, Лем во „Киберијадата“ успеал да направи спој од футуролошко-филозофски есеј, бајка и благородничка гачка. Благородничката гачка е специфичен литературен вид во полската наративна проза, настанат во XIX в., а со потекло од усните преданија. Раскажувањето во полската благородничка традиција имало многу поголемо влијание од пишаниот збор, па ваквиот литературен вид, со слободна композиција, наратор кој е претставник на народот, тематика која ги засега сите, мора да се одликува со разговорен јазик. Разговорниот јазик, пак, 
е форма на јазикот која е забележливо маркирана во поглед на емотивноста и експресивноста. Се карактеризира и со честа појава на фразеологизми од секојдневниот говор. А фразеологизмите спаѓаат во проблемот на непреводливоста, поради тешкотиите во пронаоѓањето соодветен еквивалент во различни јазици, бидејќи нивното значење е детерминирано од определен културен контекст, честопати својствен само за дадената средина. Сепак, некои јазици, како во случајов, македонскиот и полскиот, имаат слични поимски вредности во однос на некои поговорки и фразеологизми, па можат да се најдат еквиваленти, како во следниов пример:

[...] pomedytowawszy więc dobrą chwilę, doszedł do przeświadczenia, że i w tym wypadku nie wszystko stracone, można bowiem tak uczynić, aby i król pozostał syty, i jego dawni poddani - cali. ${ }^{11}$

[...] извесно време медитирајќи, дошол до просветление, дека во овој случај не е сѐ загубено, бидејќи може да се направи така, и кралот да остане сит и неговите поранешни поданици на број. ${ }^{12}$

Овде се работи за пренесување на добро познатата народна поговорка во контекст на лемовиот расказ, со менување на првиот субјект од „волк“ во „крал“ и на вториот субјект од „овци“, односно „коза“ во полската варијанта, во „поданици“. Но и во двата јазика оваа поговорка е речиси идентична - пл. $i$ wilk syty i koza cała; мк. и волкот cum, и овците на број, а во полскиот јазик, покрај овде употребената поговорка, функционира и поговорката со „овца“: $i$ wilk syty $i$ owca cała.

Потешко е да се пронајде еквивалент на фразеологизам, кому му нема целосен или делумен еквивалент во целниот јазик на преводот, како што е случајот во следниов пример:

[...] ponieważ smok, widząc, że z nim źle, z przestrzeni realnej chroni się do konfiguracyjnej. ${ }^{13}$

[...] бидејќи змејот, гледајќи дека црно му се пишува, од реалното пространство се скрива во конфигурациското. ${ }^{14}$

Може да се каже дека овде преведувачката одлично се справила со овој предизвик, бидејќи лесно може да се потпадне во замка на буквалниот превод.

11 S. Lem, 2012: Cyberiada..., s. 106.

12 С. Лем, 2018: Киберијада..., s. 160.

13 S. Lem, 2012: Cyberiada..., s. 65.

14 С. Лем, 2018: Киберијада..., s. 96. 
Дека преведувачката е свесна за тоа дека фразеологизмите се многу важен елемент за стилот на „Киберијадата“, кој треба да се пренесе и во македонскиот превод, сведочи и следниот пример, каде што таа употребува мошне сликовит и експресивен фразеологизам во преводот, додека во оригиналот се работи за неметафорски израз.

Osoby prymitywne, nie mogąc pojąć, jak to się dzieje, domagają się nieraz w zacietrzewieniu, aby im pokazać tę przestrzeń konfiguracyjną; ${ }^{15}$

Примитивните личности без да можат да си појмат како ли се случува тоа, не еднаш како слепи за стап се фаќаат да им биде покажано тоа конфигурациско пространство; ${ }^{16}$

Во оригиналот има глаголска именка која означува „тврдоглавост“на субјектот, додека во преводот на македонски е употребен фразеологизам кој означува „тврдоглаво следење на нечиј став“, па може да се каже дека има семантичка еквиваленција.

Со оглед на тоа дека се работи за еден вид бајка и застарена литературна форма на раскажување, нормално е во ова дело да се појават и архаизмите како дополнителен предизвик и тешкотија за преведувачот на „Киберијадата“ од Лем. Многу е лесно да се преведе архаизам, кога за одреден збор постои застарена форма и во двата јазика, многу често заемка од некој трет јазик. Таков е примерот со „пуд“ (pl. „pud”), кој означува стара руска мерка за тежина и егзистира и во двата јазика. Но во други случаи, преведувачот треба да биде креативен и да му даде на текстот тон на застареност, со тоа што ќе примени архаизми онаму каде што ќе можат да се применат. Значи, веќе не станува збор за лексичка и семантичка еквиваленција, туку за стилизирање на текстот. Во овој превод преведувачката го прави токму тоа, па така, се појавува „стерна“како еквивалент на полскиот збор „studnia“ („бунар“), кој не е стилски маркиран во оригиналот. Понатаму, се појавува „одрубена глава“ наместо стандардното „отсечена глава“ за полскиот израз: odcięta głowa. Оваа глаголска придавка, и на места глаголот, е позајмена од српскиот јазик, а многу ретко се среќава во македонски текстови и претставува разговорна варијанта, но во случајов ја исполнува замислената функција. Слична е и примената на „пристане“ наместо „се согласи“. Преведувачката на „Киберијада“ го употребува и архаизмот „колесница“ за богато украсена кола, иако во полскиот оригинал нема архаизам на тоа место. Исто така, ги зачестила застарените форми

15 S. Lem, 2012: Cyberiada..., s. 65.

16 С. Лем, 2018: Киберијада..., s. 96-97. 
на партиципот на -ум, кои функционираат како определби на глаголско дејство, а поретко се употребуваат во современиот јазик, како, на пример, „клечешкум“. Интересна е и употребата на зборови кои не се архаизми, но се помалку познати во стандардниот македонски јазик, наместо зборовите кои вообичаено се применуваат во тие контексти, сѐ со цел да се стилизира јазикот на преводот и да отскокнува од нормата. Такви се, на пример, „сапи“ (заден дел од телото на некои животни) и „знајно“ (наместо „познато“). Па, во тој поглед може да се каже дека преведувачката одлично се справила со овој предизвик.

Кога веќе зборуваме за стилизација, во „Киберијадата“ имаме конфронтирање на две крајно спротивни стилизации - имено, стилизирање на текстот да личи на бајка, од една страна, и од друга - научно-техничка стилизација. Ваквиот контраст е одразен и во дел од употребените неологизми во делото. Кај Лем нема едноставно спојување на два сосема различни зборови од сосема различни сфери, туку се работи за нивно контаминациско вкрстување и преметнување. Овие неологизми се разликуваат од типичните неологизми во научно-фантастичната литература. Станислав Барањчак ${ }^{17}$ ги нарекува анахрони контаминации. Овој назив значи дека неологизмите се засноваат на спојување на два израза (понекогаш непрепознатливи) кои припаѓаат на различни семантички полиња и на различни историски епохи, а притоа не се работи за обична зборообразувачка спојка - на пример, наместо да употреби „elektrorybałt“ - elektro + rybałt (застарен назив за „пејач, бард“), Лем употребува „elektrybałt“, при што спојува две зборообразувачки основи со еден глас кој се појавува во двете - „elektRybałt“. Слично е со називот на друштвената игра со монети (доста позната во Полска) „суmbergaj“ - авторот прави спој од „суbernetyka“ („кибернетика“) и „суmbergaj“ преку контаминација, односно разбивање на првиот дел од називот на играта со префиксот „кибер-“, со цел да предизвика комичен ефект. За жал, голем дел од овие анахрони контаминации во „Киберијадата“ се семантички „непрозрачни“, тешко е да се препознае нивниот втор елемент, па се транслитерираат во преводот, со исклучок на првиот елемент: кибергај, електрибалт, кибербеци, кибернарди, киберноси, киберумаки итн. Оние кои се семантички препознатливи, пак, се преведени соодветно на македонски: киберкоњ, киберштерка, киберберис, див киберис и сл.

17 S. Barańczak, 1972: Elektrycerze i cyberchanioły. „Nurt”, nr 8. Dostępne w Internecie: https://solaris.lem.pl/ksiazki/beletrystyka/cyberiada/442-recenzja-cyberiada-elek trycerze-i-cyberchanioly [dostęp: 7.09.2019] (заб. сопствен превод од полски на македонски на цитатот). 
Неологизмите на Лем во „Киберијадата“ во голем дел се хумористично маркирани, соодветно на целокупниот наратив, и преведувачката многу често успешно го доловува тој ефект, како на пример: „śmigłodrygło“ со значење на „пропелер“, таа го пренесува како „вртума“, што е контаминација на постоечкиот збор „вртимушка“ со значење на “играчка што се врти околу својата оска“; човечкиот вид го нарекува „лигавци“, што одговара на ироничниот тон кон луѓето што го зазема нараторот на Киберијадата и на оригиналниот назив „,bladawiec“ (некој што е многу блед).

Самата преведувачка, Милица Миркуловска, вели дека „[на] зборови тесно врзани за спецификата на изразот на полскиот јазик, [им треба] поголема интервенција на преведувачот на македонски јазик... Адаптирајќи вакви примери за македонскиот читател, неопходно е да се процени дека таквата алузија за еден македонски читател е премногу далечна, па тие се оставаат во оригиналната своја форма, со извесни фонетски адаптации кон македонскиот јазик“.

Оваа куса анализа на некој начин го заокружува процесот на преведување на „Циберијадата“, укажувајќи на тешкотиите и стратегиите кои преведувачот треба да ги преземе за да го долови јазичното богатство содржано во делото на Лем. Се разбира, таа не ги исцрпува сите преведувачки предизвици во јазикот на „Киберијадата“. Таа само задира во некои од нив. Остануваат уште многу проблеми, загатки, непреводливи елементи, интригантни постапки на превод, интересни преводни решенија, но тие може да бидат предмет на некој пообемен стручен труд од оваа област.

\section{Користена литература}

Barańczak S., 1972: Elektrycerze i cyberchanioły. „Nurt”, nr 8. Dostępne w Internecie: https://solaris.lem.pl/ksiazki/beletrystyka/cyberiada/442-recenzja -cyberiada-elektrycerze-i-cyberchanioly [dostęp: 7.09.2019].

Grochowiak S., 1965: Jaki śmieszny Lem! „Nurt”. Dostępne w Internecie: https:// solaris.lem.pl/ksiazki/beletrystyka/cyberiada/351-recenzja-cyberiada-jaki -smieszny-lem [dostęp: 7.09.2019].

Jarzębski J., 1983: Science fiction a polityka. „Pamiętnik Literacki”, R. 74, z. 2, s. $83-113$.

18 М. Миркуловска, 2018: Киберијада - барокот на космосот. „Folia Philologica Macedono-Polonica", t. 9/10, c. 282-283. 
Lem S., 2012: Cyberiada. Kraków, Cyfrant [e-book].

Лем С., 2018: Киберијада. М. Миркуловска, прев. Скопје, Антолог.

Миркуловска М., 2018: Киберијада - барокот на космосот. „Folia

Philologica Macedono-Polonica", t. 9/10, s. 282-283.

\section{Lidija Tanuševska}

\section{Wyzwania przekładu Cyberiady Stanisława Lema}

STRESZCZENIE | Artykuł ma na celu pokazać, dlaczego tak trudno tłumaczy się Lema, a szczególnie Cyberiadę. Uwagę skupiono na stylu pisarza i trudnościach translatorskich z nim związanych. Na podstawie dokonanej analizy można stwierdzić, że problem w deszyfrowaniu i przetłumaczeniu stanowią nie tylko neologizmy, lecz także związki frazeologiczne, archaizmy, język poetycki, modele słowotwórcze itp. Wszystkie te środki językowe nadają narracji wydźwięk baśniowo-futurystycznej gawędy, co było zamiarem Lema. Tłumacz, mając na uwadze, że w przekładzie dodatkowo powinien przenieść także obraz cudzej kultury, staje przed zadaniem niemal niemożliwym do wykonania.

SŁOWA KLUCZOWE | science fiction, język, stylizacja, archaizmy, neologizmy

\section{Lidija Tanuševska}

\section{The Challenges of Translating The Cyberiad by Stanisław Lem}

SUMMARY | This text aims to show why is it so difficult to translate Lem, especially in the case of The Cyberiad. Attention is paid to the style of Lem's language and to the translation difficulties associated with it. The analysis shows that the text contains difficult-to-translate features, including neologisms, idioms, archaisms, poetic expressions, wordformation models, and more. The accumulation of these features creates the tone of fairytale futurism found in Lem's original stories. The translator, who, on top of faithfully transmitting all of these intricate details, must also bear in mind the responsibility to carry forward an impression of the author's home culture, is thus faced with a nearly insurmountable task.

KEYWORDS | science-fiction, language, stylization, arhaisms, neologisms

LIDIJA TANUŠEVSKA | prof. dr hab., pracuje w Katedrze Slawistyki na Wydziale Filologicznym im. Blaže Koneskiego Uniwersytetu Świętych Cyryla i Metodego w Skopju w Macedonii. Jej zainteresowania badawcze koncentrują się głównie wokół zagadnień przekładoznawstwa, a także językoznawstwa porównawczego i literaturoznawstwa. Jest wybitnym tłumaczem literatury polskiej na język macedoński. Została wyróżniona nagrodami translatorskimi, m.in. Nagrodą im. Ryszarda Kapuścińskiego za przekład Imperium na nowy język (2015). W 2017 roku wydała monografię Przyczynek do gramatyki konfrontatywnej języka 
macedońskiego i języka polskiego. Przełożyła książki: Bieguni, Prawiek i inne czasy oraz E.E. Olgi Tokarczuk, a także opowiadania i nowele m.in. Cypriana Kamila Norwida, Brunona Schulza, Stefana Grabińskiego. 


\section{Przekłady serbsko-polskie i polsko-serbskie}

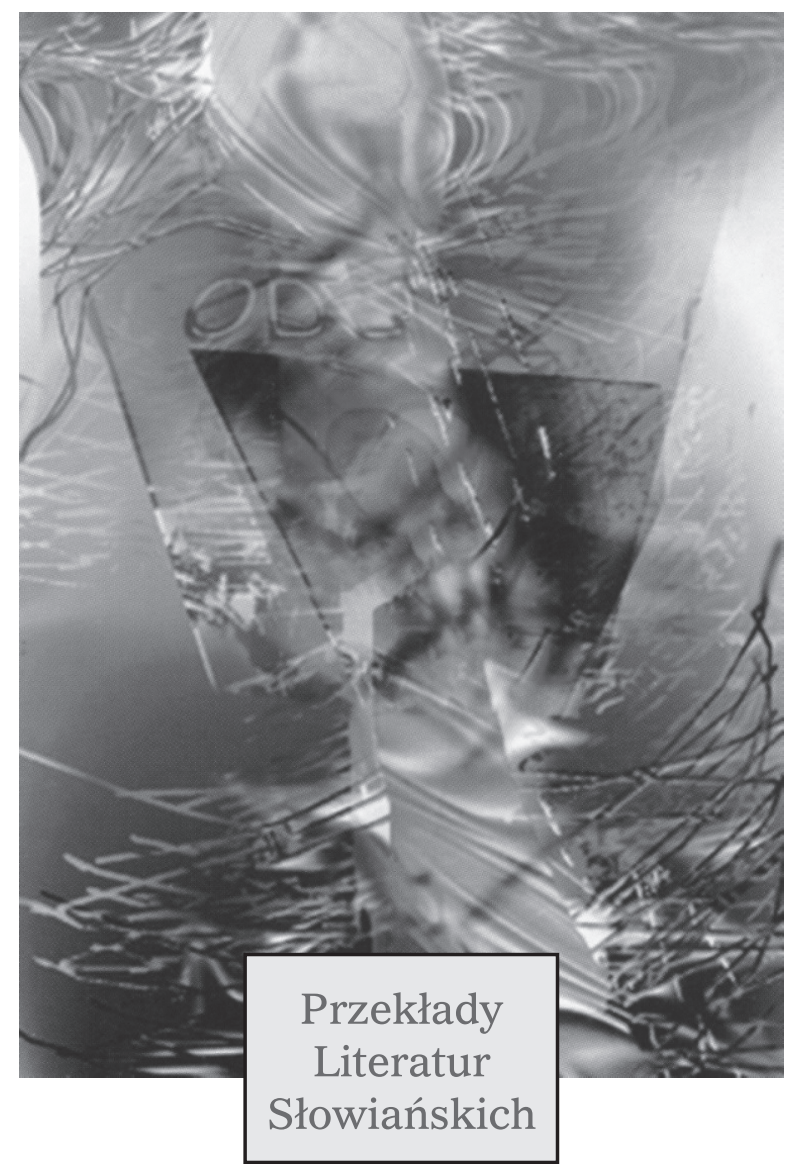


